\title{
Imagining the Rule of Law in Nineteenth- Century Britain: Liberal Society and the Dialectic of the Clan
}

\author{
Mark S. Weiner*
}

\begin{abstract}
In this essay, I provide a historical and theoretical framework for understanding the imaginative relation between the liberal rule of law and the kin-based form of socio-legal organization I call 'the rule of the clan' - a classic example of law created 'from below'. Specifically, I believe that a culturalist disciplinary perspective reveals that the modern liberal state and its more centralized rule of law always stand in an ironic, dialectical relation to the rule of the clan as a legal form. Liberal society, that is, nurtures itself through an anti-liberal utopian imaginary. This article provides an intellectual history backdrop for theorizing that dialectical relationship by examining two contrasting ways in which nineteenthcentury British intellectuals imagined the rule of law. Following the work of Charles Taylor and, more specifically in the legal field, Paul Kahn, my goal is to depict a social imaginary of modern liberalism that has been neglected within contemporary liberal theory - and, in doing so, provide a way to appreciate the cultural foundations of liberal legality. The article considers the stories that nineteenth-century British intellectuals told about the relation between the rule of law and the rule of the clan as a way to think about the rule of law today. It thus tacks between three different shores: the world of legal pluralism (the rule of the clan), the world of nineteenth-century British analysis of the rule of the clan and the contemporary relation between culture and modern liberal society.
\end{abstract}

Keywords: clan, rule of law, Albert Venn Dicey, Walter Scott, legal memory
Mark S. Weiner is author of Black Trials: Citizenship from the Beginnings of Slavery to the End of Caste (New York: Alfred A. Knopf, 2004), recipient of the Silver Gavel Award of the American Bar Association, and Americans without Law: The Racial Boundaries of Citizenship (New York: New York University Press, 2006), winner of the President's Book Award of the Social Science History Association. He received an A.B. in American Studies from Stanford University; a Ph.D. in American Studies from Yale University; and a J.D. from Yale Law School. He blogs at Worlds of Law (www.worldsoflaw.com).

\section{Recuperating a Culturalist Legal Tradition}

In this essay, I provide a historical and theoretical framework for understanding the imaginative relation between the liberal rule of law and the kin-based form of socio-legal organization I call 'the rule of the clan' - a classic example of law created 'from below'. ${ }^{1}$ Specifically, I believe that a culturalist disciplinary perspective reveals that the modern liberal state and its more centralized rule of law always stand in an ironic, dialectical relation to the rule of the clan as a legal form. ${ }^{2}$ Liberal society, that is, nurtures itself through an anti-liberal utopian imaginary.

This article provides an intellectual history backdrop for theorizing that dialectical relationship by examining two contrasting ways in which nineteenth-century British intellectuals imagined the rule of law. Following the work of Charles Taylor and, more specifically in the legal field, Paul Kahn, my goal is to depict a social imaginary of modern liberalism that has been neglected within contemporary liberal theory - and, in doing so, provide a way to appreciate the cultural foundations of liberal legality. ${ }^{3}$ The article considers the stories that nineteenth-century British intellectuals told about the relation between the rule of law and the rule of the clan as a way to think about the rule of law today. It thus tacks between three different shores: the world of legal pluralism (the rule of the clan), the world of nineteenthcentury British analysis of the rule of the clan and the contemporary relation between culture and modern liberal society.

The first tradition of rule-of-law analysis I examine, associated especially with Albert Venn Dicey, built a conceptual edifice of interlocking struts and beams, ideas and structures, to describe law's rule. These intellectuals defined the rule of law in abstract, analytic terms, seeking to describe its essential components as it

1. M.S. Weiner, The Rule of the Clan: What an Ancient Form of Social Organization Reveals about the Future of Individual Freedom (2013).

2. For a study that sketches a similar dialectical relationship in relation to western conceptions of law more generally, see P. Fitzpatrick, The Mythology of Modern Law (1992).

3. C. Taylor, Modern Social Imaginaries (2004) 23-30; P.W. Kahn, Political Theology: Four New Chapters on the Concept of Sovereignty (2011). 
appears across varying legal systems and constitutional arrangements. By contrast, the other tradition of legal historians, historical novelists, and liberal state-builders theorized from the ground up. They trained their interpretive attention on the myriad details of social and cultural life that either enabled or threatened the rule of law. Taking as their premise the assumption that law existed in dynamic relation with culture, they attempted to understand and promote those modes of lived experience, both individual and collective, that could support the liberal rule of law. ${ }^{4}$ While the conceptual account gave rise to a still-vibrant tradition of scholarship about the state and legality, the culturalist approach has been largely lost to legal studies. Yet I believe that the culturalist tradition contains vital resources for a legal analysis of what the rule of law represents and how it can be sustained.

I focus here on Britain in the nineteenth century for both a substantive reason and, more important, a methodological one. The substantive reason is that Britain has a rich, well-documented clan history, and many readers of the Erasmus Lam Reviem will be at least somewhat familiar with it, particularly the history of clans in medieval and early-modern Scotland. Although the dynamics of clan society in Britain are rarely associated with troubled regions of the world today such as Afghanistan or Somalia, the basic legal and cultural issues they involve are strikingly similar. Britain thus provides a focal point within a broad comparative view because it challenges common preconceptions of the rule of the clan's provincialism. It emphasizes the fact that the clan is a universal socio-legal phenomenon.

The methodological reason for turning to Britain, and specifically Britain in the nineteenth century, is more complex, but worth parsing. At the broadest level of remove, I believe a culturalist framework of analysis can build on the writing of a relatively neglected group of nineteenth-century liberal intellectual reformers who saw constitutional and legal questions as fully intertwined with aesthetic and cultural matters. Writing before the full professionalization of the disciplines, these men forwarded a vibrant if unsystematic form of analysis that sought to describe in precise, anthropological detail the cultural foundations of the new liberal nations they were seeking to wrest into being, and they were attentive to the aesthetic qualities of liberalism and its legal traditions. Their early precursor was Edmund Burke, but their more immediate community of discourse included men such as Domingo Sarmiento in
Argentina, Jón Sigurðsson in Iceland, and István Széchenyi in Hungary. ${ }^{5}$

This group of liberal state-builders was beginning to say something very interesting about the relation between culture and the rule of law and to develop a robust tradition of liberal legal-cultural analysis, but the abstract, theoretical approach exemplified by Dicey's writings pushed their work to the margins of legal intellectual life. I turn to nineteenth-century Britain, then, because it is there that the nascent culturalist tradition was cut short. I look back to this developing tradition, however, not to give uncritical voice to its analysis, though I view its work as valuable and inspiring in itself. Instead, I see that body of analysis as just one stage in the history of the transition from a clan society to the rule of law. In other words, I see it as an index of the changing cultural foundations of modern government. Turning to nineteenth-century Britain is part of an effort not simply of intellectual recovery but also analytic reintegration.

In the following pages, then, I consider two related issues. The first is the philosophic context of Victorian academic studies of the rule of law, which I treat through the work of Dicey, who was central to the development of the rule of law as an idea. Next, I turn to the development of various forms of socio-legal analysis that considered the fall of the clan, or extended kin network, as a primary object of political loyalty and legal authority - one of the topics through which nineteenthcentury thinkers examined the rule of law in cultural terms. ${ }^{6}$ I specifically consider how the clan was discussed within the great English-language genres of constitutional history, literary historical romance, and the history of private law. I focus especially on how nineteenth-century thinkers treated the issue of the clan of early medieval England, the distant world of the ancient Anglo-Saxons, though I also take a brief detour to the borderlands of eighteenth-century Scotland. I conclude with a few brief observations on political philosophic themes.

\section{The Rule of Law: The Analytic Approach of Albert Venn Dicey}

The origin of the modern concept of the rule of law lies in the work of English constitutional theorist Albert
4. For a broad historical backdrop to the related tension between Physis and Nomos in western intellectual history, and the conceptualization of custom, see D.R. Kelley, The Human Measure: Social Thought in the Western Legal Tradition (1990).

5. For my views of Sarmiento, see 'Domingo Sarmiento and the Cultural History of Law in the Americas', 63 Rutgers Law Review 3, 101-115 (2011). I have discussed my views of Burke in "“Political Culture" and the Concept of Law as an Aspect of Early Modern Citizenship: Burke, Herder, Savigny', Symposium on Comparative Early Modern Legal History, Center for Renaissance Studies, Newberry Library, Chicago, IL, November 2005 (unpublished paper available upon request).

6. For a wide-ranging historical analysis of the changing intellectual treatment of the Roman clan (gens), see C.J. Smith, The Roman Clan: The Gens from Ancient Ideology to Modern Anthropology (2006). 
Venn Dicey. ${ }^{7}$ Born in 1835 , Dicey was raised in the lofty circles of the Victorian liberal intelligentsia, and he has the kind of biography which inspires the envy academics often feel when reading about nineteenthcentury men of letters. He was the son of one of the most prominent publishers of his time; his mother personally taught him Greek and Latin when he was a child; Darwin was a relative, and he counted Sir James Fitzjames Stephen as his cousin (and so was related by marriage to the great legal historian Frederic Maitland); at Balliol College, he was a student of Benjamin Jowett, known today for his beautiful translations of Plato; and a few years after being called to the bar at Inner Temple, he toured the United States with his friend Lord Bryce, author of The American Commonmealth (1888), a classic portrait of the US political scene.

In 1885 , three years after assuming the Vinerian professorship of law at Oxford, a chair first held by William Blackstone, Dicey published a treatise on the basis of his inaugural lectures. Introduction to the Study of the Lam of the Constitution quickly became a touchstone of AngloAmerican legal thought. Dicey sought to describe the central characteristics of English government, the most important of which was the rule of law. Dicey defined the rule of law in Britain in terms of three critical attributes. The first was the absence of arbitrary government power (in his words, 'that no man is punishable or can be lawfully made to suffer in body or goods except for a distinct breach of law established in the ordinary legal manner before the ordinary Courts of the land'). ${ }^{8}$ The second was equality before the law (that is, 'that every man, whatever be his rank or condition, is subject to the ordinary law of the realm and amenable to the jurisdiction of the ordinary tribunals'). ${ }^{9}$ And the third was the fact that constitutional law in Britain arose from the decisions of judges adjudicating private disputes, rather than being imposed by a code from above. Therefore, as a conceptual matter, individual rights were not the consequence of constitutional law but rather its source, and so they were less capable of suspension than under systems of civil law on the continent.

Dicey's discussion of the rule of law remains profoundly influential today. His definition is the basis for nearly all subsequent accounts of the concept. The argument that the rule of law involves constitutionally constrained government and individual legal equality, whatever those notions might mean in their details, is the point of origin to which scholars from economist Friedrich Hayek to philosopher Joseph Raz trace their work, citing Dicey's analysis as foundational before turning to

7. On Dicey, see R.E. Michener, 'Foreword', in A.V. Dicey, Introduction to the Study of the Law of the Constitution (1982 [1885]) xi-xxiii. For a recent survey of approaches to the rule of law, see B.Z. Tamanaha, On the Rule of Law: History, Politics, Theory (2004). In this discussion, I set aside the tradition of critical analysis of the rule of law associated with Western Marxism

8. A.V. Dicey, Introduction to the Study of the Law of the Constitution (1982 [1885]), at 110

9. Ibid., 114 elaborate, supplement, or modify his principles. ${ }^{10} \mathrm{He}$ supplied liberals with their essential terms of analysis, the basic vocabulary with which the rule of law is described today - and for this, he is widely celebrated. Moreover, Dicey shaped scholarly analysis in a manner that is not often acknowledged; indeed, it is typically taken for granted. The approach and analysis that he pursued, and that subsequent writers followed, seeks to define the rule of law in imminent conceptual terms. His is largely a de-historicized look from above, which renders both his work and the analytic tradition of rule of law scholarship it established resolutely abstract, focused on philosophical terms and their precise definitions.

Dicey's scholarship contrasts notably in this respect with the culturalist approach. ${ }^{11}$ This approach attracted Dicey, but he deliberately chose not to follow it. Dicey's repudiation is evident especially in the second section of Lam of the Constitution, where he theorizes the nature of the rule of law and establishes his analytic orientation by explicitly excluding a culturalist analysis. Significantly, Dicey begins this discussion not by directly advancing the three kindred notions at the heart of his definition, but instead by describing a very different academic project and justifying his reasons for not pursuing it. This alternative project would have centered on what he evocatively called 'the legality of English habits and feeling' - in other words, just what it was that made English culture seem so eminently compatible with liberal institutions, a phenomenon a great many foreign observers noted at the time. ${ }^{12}$ In this regard, Dicey discusses at length a comparison of England and Switzerland made by Alexis de Tocqueville in which the Swiss come off rather badly as lacking true democratic values (the future of federal Switzerland was a key interest for many liberals then, much as the fate of Turkey is today). '[I]f violence were to destroy the Republican institutions in most of the Swiss Cantons', writes Tocqueville in a characteristic part of a passage from which Dicey quotes (the passage is the longest quotation in his book):

it would be by no means certain that after rather a short state of transition the people would not grow accustomed to the loss of liberty. In the United States

10. See, e.g., F.A. Hayek, The Constitution of Liberty: The Definitive Edition, The Collected Works of F.A. Hayek, Vol. 17, ed. R. Hamowy (2011 [1960]) 306, and Joseph Raz's discussion of the formal conception of law and citation and criticism of Dicey in 'The Rule of Law and Its Virtue', in J. Raz, The Authority of Law (2009) 210-229, at 218, n. 7.

11. Dicey's scholarship also differs dramatically from the analysis offered today in the occasional policy publications of development NGOs. These tend to be practical treatments of specific national problems and particular state institutions written to solve local challenges rather than to develop more general theoretical or historical frameworks of analysis. See, e.g., United States Institute of Peace, Establishing the Rule of Law in Afghanistan, Special Report No. 117 (March 2004), <www.usip.org/ publications/ establishing -rule -law -afghanistan> (accessed 14 May 2012). For a discussion of the implications of competing definitions of the rule of law for practitioners, see R.K. Belton, 'Competing Definitions of the Rule of Law', Carnegie Papers, Rule of Law Series, Democracy and Rule of Law Project, No. 55 (January 2005).

12. Dicey, above n. 8, at 108. See also R. Gneist, History of the English Constitution, trans. P.A. Ashworth (1886). 
and in England there seems to be more liberty in the customs than in the laws of the people. In Switzerland there seems to be more liberty in the laws than in the customs of the country. ${ }^{13}$

The Swiss, in other words, live under the rule of law because of the political commitments and strength of their state; the English live under the rule of law because of their culture, of which their state is but one reflection.

Dicey was ambivalent about this type of analysis, for even as he believed Tocqueville was on to something very important, he also was frustrated by his lack of terminological precision. Most especially, just what was this 'liberty' to which the Swiss were culturally unaccustomed and for which the English seemed so temperamentally suited? How could one define it precisely? What were its component parts? Tocqueville at least was unclear on the point. And it is here that Dicey begins his own work - commencing with a modest nod suggesting that if Tocqueville could not successfully complete such a project, nobody could; then expressing a desire to overcome Tocqueville's characteristic lack of terminological precision; and then launching into the extended philosophical treatment of the rule of law that established the tradition of analysis still dominant today. Dicey does not reject in principle the study of the cultural foundations of English legality. Instead, he describes his own study as something to be undertaken 'first', as a prelude to a more informed discussion of the way the rule of law was rooted in common habits and feeling. ${ }^{14}$ Ironically, however, his own analysis had such a deep impact that scholars never returned to the discussion of law and culture which may have encouraged him to undertake his project from the start. As a consequence of the very philosophical strength of his work, the study of the rule of law instead became almost conceptually bound to the exclusion of a culturalist analysis. The force of this exclusion can be seen not only in the dominance of Dicey's analytic model, but also in the unfortunate fate of the project he declined to pursue, which could have been immensely enriched over time had legal scholars chosen to return to it with the fruits of analytic jurisprudence. The writings of Tocqueville, for instance, ultimately spawned a body of national values research that takes as its central concern not law's rule, or even law, but rather 'community' life and its voluntary associations (a good example is Robert Bellah et al., Habits of the Heart). ${ }^{15}$ The Tocquevillean sociological tradition, that is, became isolated from a concern with specifically legal forms. At the same time, many scholars who have called for a cultural turn in legal scholarship, those with the training to think in precise doctrinal and legal categories, rarely engage in the thick anthropological analysis, inspired by the work of Clif-

\footnotetext{
3. Dicey, above n. 8, at 109.

14. Ibid., at 110

15. R.N. Bellah et al., Habits of the Heart: Individualism and Commitment in American Life (2007 [1985]).
}

ford Geertz, that might illuminate the rich cultural particularity and, in the words of Pitirim Sorokin, the structures of 'logico-meaningful integration', in which law finds its force. ${ }^{16}$ Their work instead tends to have an abstract, neo-Kantian flavor, focused on moral abstractions rather than factual particulars. Lacking is a form of analysis that would link reflection on specific cultural forms, the kind Dicey had in mind when he spoke of English habits and feeling, and which he surely observed during his American travels with Lord Bryce, with the definitional precision of the rule of law that he forged in Law of the Constitution.

\section{The Liberal Rule of Law and the Fall of the Clan}

And this is where one might return to the work of Dicey's contemporaries. With a high level of sophistication, though not always with full self-consciousness, many of his colleagues were imagining the rule of law in precise cultural terms, providing through their disparate works an implicit typology of the cultural conditions required for a liberal legal system. Their approach was not that of Tocqueville, who was interested finally in the relation between culture and democracy, an essentially political concern; rather, it was a subset of that larger project that attended to specifically legal concepts and institutions. In the next section of this article, I consider how some of these thinkers treated a specific cultural component of the rule of law: the fall of the clan as an object of political loyalty and legal authority. Here, after noting the diversity of forms the rule of the clan today takes, I consider Victorian concerns about medieval law that fed into their treatment of the clan and its legal history.

Clans are tribes or tribal subdivisions, often corresponding to a geographic region, united by common descent from a real or mythic ancestor and by a strong corporate identity. In some respects, they can be considered the original form of human social organization. The rule of the clan takes three main forms, spread across a wide continuum of state development. First, and most prominently, it consists of the legal structures and cultural values of societies organized primarily on the basis of kinship - societies in which the extended family is vital for social and legal action and in which individuals have little choice but to maintain a strong clan identity. Second, the rule of the clan includes the political arrange-

16. C. Geertz, 'Thick Description: Toward an Interpretive Theory of Culture', in The Interpretation of Cultures (1973) 3-20; P. Sorokin, Social and Cultures Dynamics, 3 vols. (1937) 145. For one contemporary scholar's influential approach to the cultural study of law, partly influenced by Geertz, see P.W. Kahn, The Cultural Study of Law: Reconstructing Legal Scholarship (2000); for a later, compelling interpretation by that same scholar of modern popular cultural texts, see P.W. Kahn, Finding Ourselves at the Movies: Philosophy for a New Generation (2013). 
ments of societies governed by 'clannism'. ${ }^{17}$ These societies possess the outward trappings of a modern state but are founded on informal patronage networks, especially those of kinship, and traditional ideals of patriarchal family authority. In nations pervaded by clannism, government is coopted for purely factional purposes and the state treats citizens not as autonomous actors but rather as troublesome dependents to be managed. Finally, and most broadly, the rule of the clan includes the range of communal associations that grow within the modern state when its authority is weak or in places where its writ fails to run, such as inner cities. These three variant forms of the rule of the clan are united in an important respect. In comparison to modern liberal societies, communities governed by the rule of the clan possess far more limited social space for personal, individual freedom. This is because the rights and obligations of individuals are deeply influenced by their places within the kin groups to which they inexorably belong. In societies where group solidarity is a preeminent value, people lack what the late Palestinian intellectual Hisham Shirabi called 'the individual's claim to autonomous right' ${ }^{18}$

The meaning of the clan today involves most evidently its continuing role as a political actor in places such as Central Asia and the Caucuses and its surprising persistence in the face of colonial and Soviet programs of socio-economic modernization. ${ }^{19}$ Nineteenth-century British writers, similarly, examined the clan in its contemporary political dimensions, especially in their writings on colonial policy in India. More important, though, the subject also returned them to a lost world, to Anglo-Saxon England and continental Germanic law after the fall of the western Roman empire. ${ }^{20}$

In nineteenth-century Britain, the early middle ages were a subject of great fascination not only for historians, but also for intellectuals and artists generally. ${ }^{21}$ The perceived organic harmony of medieval England and northern Europe, in particular, served as a powerful point of protest against the fragmentation, conflict and anomie of modern life, providing a ready avenue for social criticism. The influence of medieval thought can thus be seen at work upon figures as dissimilar as

17. United Nations Development Programme, Regional Bureau for Arab States, Arab Human Development Report 2004: Towards Freedom in the Arab World (2005) 145-146.

18. H. Sharabi, Neopatriarchy: A Theory of Distorted Change in Arab Society (1988) 46.

19. For two studies of such persistence, see K. Collins, Clan Politics and Regime Transition in Central Asia (2006) and E. Schatz, Modern Clan Politics: The Power of 'Blood' in Kazakhstan and Beyond (2004).

20. On India, see for instance the writings on India of John Stuart Mill and Henry Sumner Maine. See L. Zastoupil, John Stuart Mill and India (1994) and K. Mantena, Alibis of Empire: Henry Maine and the Ends of Liberal Imperialism (2010).

21. See A. Chandler, A Dream of Order: The Medieval Ideal in NineteenthCentury English Literature (1970). See also R.H. Bloch and S.G. Nicols (eds.), Medievalism and the Modernist Temper (1996); S. Collini, English Pasts: Essays in Culture and History (1999) and A.D. Culler, The Victorian Mirror of History (1985). Much of the discussion below also implicates the relation between British and German historical writing, on which see B. Stuchtey and P. Wende, British and German Historiography, 1750-1950: Traditions, Perceptions, and Transfers (2000).
Cardinal Newman and those who followed him into the Catholic Church and the hothouse flowers of the PreRaphaelite circle.

Legal thinkers, too, were fascinated by how the medieval world reflected upon present-day realities, but with an important caveat. Whereas a good deal of Romantic and Victorian medievalism was reactionary in spirit, legal thinkers were most nearly always of a liberal temper. This is not to say they all were Whigs at the ballot box, but rather that they valued democratic government, private property, and individual liberty, and that though they often spoke of the middle ages in a reverential tone, they never indulged in fantasies of returning to them. Instead, they were central figures in the great conceptual achievement, described by historian J.W. Burrow, in which nineteenth-century liberals yoked a pious respect for the past to a belief in progressive historical development by finding in early Anglo-Saxon society the wellspring of English liberty. ${ }^{22}$ From this perspective, whose origins lie in the sixteenth century but which was given substantially new form and complexity within the modern social sciences, the medieval legal past was not a point of departure from which Britain made a political descent, nor a vantage to be denigrated as merely that of a benighted history (as it would become in France). Rather, the medieval past was the vital source of contemporary liberal institutions, whose very survival relied upon a continual imaginative engagement with it.

Such engagement was seen as directly countering the anxieties about the fate of modern liberal government that historians brought to their study of medieval law. Victorian intellectuals identified a range of challenges posed by liberalism to individual citizens and to the soul of the nation at large, but perhaps the most concerning of them was the danger of social disorder - or, to be more precise, and to use one of the keywords of the British nineteenth century, the threat of 'lawlessness'. This threat arose, many intellectuals believed, because liberalism tended to facilitate personal freedom by removing ordinary people from a vital connection with what nineteenth-century German liberal scholar Otto von Gierke evocatively called the 'noble edifice' of 'organic associations', including family, tribe, guild, and nation - a process of separation that diminished individual identification with the law, which had grown upon this organic, communal framework. ${ }^{23}$ Liberalism, that is, severed people from the concrete and personal element of law that gave it psychological force and allowed it to serve as an instrument of social control. This anxiety was felt not only in regards to civic life in Britain, but also in relation to the international legal order, which liberals were beginning to imagine and which they believed would demand new forms of identification with a distant transnational state.

22. See J.W. Burrow, A Liberal Descent: Victorian Historians and the English Past (1981).

23. O. von Gierke, Community in Historical Perspective [Das deutsche Genossenschaftsrecht (1868)], trans. M. Fischer, ed. A. Black (1990), 2. 
Medieval Germanic law, by contrast, was a legal system so concrete in its establishment of legal relations, so richly cultural in its animating principles and external forms, that the folklorist Jacob Grimm, one of the Brothers Grimm and a student of jurist Karl Friedrich von Savigny, enthusiastically spoke of its 'poetic' and 'sensuous' quality. ${ }^{24}$ In this ancient Germanic world, a seller would release all claims to land by extinguishing the fire in his hearth and delivering a clod of soil to the buyer; a widow would free herself from liability for her husband's debts by placing her house key upon his funeral bier; a man would remove himself from liability for his family's crimes (though also from inheriting their wealth) by breaking a bundle of alder branches and throwing them into the four corners of a courtroom; a hand-clasp or a bow of the head established lifelong feudal relationships; and legal codes were filled with alliterative compounds and rhymes, such as 'Erbe und Eigen' (heritage and title) or 'wer darf jagen darf auch hagen' (he who has the right to hunt may also enclose the land). ${ }^{25}$ In Anglo-Saxon England, which revealed Germanic law in its least admixed form (that is, removed from the influence of Rome), the law was a phenomenon for the eyes, ears and touch. It was a common belief among nineteenth-century writers that liberal government might be sustained into the future only if it could acquire a similar cultural rootedness and power (thus, for instance, Bagehot's celebrated discussion of the 'ornamental' aspects of the English constitution). ${ }^{26}$

Writing about the legal significance of the clan provided one way for British writers to connect modern liberal institutions with this original cultural authority. It offered, in this respect, a dual approach to the cultural preconditions of the rule of law: first, an analysis of the development of the rule of law out of organic principles of kinship and their transformation in the distant past and, second, the development of a particular memory of that history as a cultural and aesthetic strategy to maintain the rule of law in the present day. This dual approach animates three great genres of nineteenthcentury British letters - constitutional history, literary historical romance, and the history of private law, especially that of real property - each of which tells a similar story about the clan and, as important, follows a parallel strategy to its representation. In each instance of the form I discuss in the following section, I consider writ-

24. J. Grimm, 'Von der Poesie im Recht', II Zeitschschrift für Geschichtliche Rechtswissenschaft, 25-99, at 25 (1816); R. Schmidt-Wiegand, 'Das sinnliche Element des Rechts: Jacob Grimms Sammlung und Beschreibung deutscher Rechtsaltertümer', in L. Denecke (ed.), Kasseler Vorträge in Erinnerung an den 200. GeburtstagderBrüder Jacob und Wilhelm Grimm (1987) 1-24.

25. R. Huebner, A History of Germanic Private Law, trans. F.S. Philbrick, pref. E.G. Lorenzen, intro. P. Vinogradoff and W.E. Walz (1918) 10.

26. [W. Bagehot], Bagehot: The English Constitution, Cambridge Texts in the History of Political Thought, ed. P. Smith (2001) 143 ('Of Changes of Ministry'). For a stimulating contemporary work following in this tradition, see B.J. Hibbitts, 'Coming to Our Senses: Communication and Legal Expression in Performance Cultures', 41 Emory Law Journal, 873-960 (1992). ers who were either representative of or foundational to the genre.

\section{Three Genres of Culturalist Analysis of the Clan's Decline}

Constitutional history offers an appropriate place to begin because one of the most striking aspects of the field is the degree to which it considered English legal history in its social and cultural dimensions. The origins of this sensitivity are unclear, but they probably have something to do with the fact that the common law was formed in the context of a colonial occupation from the confluence of two distinct societies, the Germanic and the Norman, and because a national literature and a national legal code were born simultaneously in England, under the reign of the great King Alfred, a patron of both the common tongue and the administration of justice. In any event, constitutional historians of the nineteenth century tended to portray the culture of early Anglo-Saxon kinship and its ultimate destruction as the historical underpinning of the liberal principle of government under law.

This position was advanced especially in the influential works of the 1860 s and 1870 s by legal and architectural historian (and Gladstonian liberal) Edward Freeman, author of The Gromth of the English Constitution (1872) and The History of the Norman Conquestof England (1867). Like many books of the time, Freeman's work begins its larger nationalist narrative by describing the all-important transformation of Germanic notions of monarchical authority. ${ }^{27}$ The account begins in the intimate warrior societies on the continent described by the Roman historian Tacitus, in which members of a tribe voiced ascent to policies by pounding spears at communal assemblies. From these small bands centered around family groups - or kin - grew their leaders, the chiefs of the kin - or kings - who ruled over a common, homogenous group of relations (Freeman was especially fond of etymologies, and he used them with the force of romantic literary symbols). Then, in England, came an epochal change. Having crossed the North Sea, these Germanic tribal societies prospered and grew, and kings came in time to rule not over a single people so much as a common territory. They became not simply kings of the West Saxons, to take one example, but rather the Kings of Wessex and its inhabitants. A government and a culture centered around extended kinship associations began to dissolve.

From the perspective of the future liberal state, this dissolution brought both positive and negative political consequences. On one hand, the family model from

27. E.A. Freeman, The History of the Norman Conquest of England, 6 vols. (1867-1879) and The Growth of the English Constitutionfrom the Earliest Times (1909 [1872]) 
which Anglo-Saxon conceptions of kingship grew served as the framework for the formation of an institution that placed the territorialized King under increasingly formalized, quasi-democratic control. That institution was the pitangemot, the assembly of wise men - or, to follow another etymology, the assembly of family elders, or eldormen, or (from the Scandinavian) earls which elected the King and in principle could depose him. Here was the forerunner of modern parliament, and the birth of a state bound by law. At the same time, the increasingly representative character of government attenuated the personal bond between the King and his subjects that had long been central to Germanic society, and it threatened to erode the mutual feelings of loyalty and responsibility between state and citizens that was required for the maintenance of a government under law. With the waning of the clan, the state was ever less the immediate product of Gierkean organic associations. As Burrow notes, however, it was within this cultural breach that constitutional historians like Freeman found their calling. For to remedy the deleterious effects of the dissolution of Germanic society as a government of clans (otherwise politically necessary for liberalism), it was thought imperative as a matter of national civic consciousness to establish and emphasize the very kin-based pedigree and continuing Germanic resonance of modern constitutional institutions. Historians could contribute to the cultural basis of liberal government by producing a form of national memory that would enrobe presentday legal forms with the solemnity of a collective, culturally rooted ancestry, thus binding a liberal nation together through the recollection of its anti-liberal past. Freeman and others were dedicated to this ideological project, and it informed their aesthetic choices as historians throughout their work (to take one indicative example, Freeman sought to write British legal history using only words whose origin lay in England before the Norman conquest - even the Saxon defeat at Hastings would be called the battle of Senlac).

Writing 50 years earlier, and deeply influencing later constitutional historians, who read him avidly in their youth, Walter Scott treated the subject of the clan in substantially similar ways, developing a body of national memory that resolved the tension between organic associations and the individual through a literary form, the novel, often said to be specially suited to the purpose. ${ }^{28}$ This is evident not only in Scott's colorful portrayal of life among the medieval Anglo-Saxons in Ivanhoe (1819), but also in his most celebrated work, Waverley (1814), a historical romance about Scotland in 1745, the year of the failed Jacobite rebellion led by the Stuart pretender Bonnie Prince Charlie. Here begins my Scot-

28. On Scott, see J. Sutherland, The Life of Walter Scott: A Critical Biography (1995); on Scott and law, see 30-32. For a discussion of the accuracy of Scott's portrayal of medieval law, see D. Stechern, Das Recht in den Romanen von Sir Walter Scott (2002). tish detour - which is also a detour literature, an essential window onto the social imaginary of law. ${ }^{29}$

Scott's novel concerns Edward Waverley, a young man torn between the liberal, Whig sympathies of his father, who works for the Hanoverian government in London, and the Jacobite cultural tendencies of his uncle, who reared him. Scott dramatized the solution to this ideological conflict through a love plot set within a sociolegal environment. While serving in the British army, Edward is quartered in Scotland. There, he meets Rose, the sensible and family-oriented daughter of a Jacobite friend of his uncle, a Scottish baron from the lowlands. Marriage to Rose seems possible, but soon, Waverley visits the mountain hideaway of the Mac-Ivors, a colorful clan of Scotch highlanders, coming to know both their courageous leader, Chieftain Fergus, and his beautiful and fiery sister, Flora, with whom he falls in love. Waverley's marital choice thus is between two flowers: one, Flora, aptly Latinate and abstract given the Roman character of Scots law; the other Anglo-Saxon and particular, Rose.

Scott meticulously depicts the life of the Mac-Ivor clan, based on his many years of folkloric research in Scotland, and these detailed portraits comprise some of the most memorable parts of his work. ${ }^{30}$ The Mac-Ivors, importantly, are not mere cultural nationalists. They are actively engaged in paramilitary preparations for the Stuart rebellion, and the turning point in Waverley comes when young Edward joins them, drawn in by his love for Flora and the romantic life of the clan. The rebellion fails, but Edward is not lost. Through some twists of plot, he escapes execution for treason (the rebel leaders are tried and convicted in England), and he ultimately marries Rose, leaving behind the exciting life of the highlanders and their anti-liberal political commitments - all the while, however, actively kindling his experience with them into a sustaining, romantic memory. Edward will be a man of the lowlands, and a British subject, with an eternal recollection of his grand highland experience.

Scott was a lawyer by training, reared to join the family firm, and it is thus not surprising that Waverley consistently explores socio-legal themes. Indeed, the novel could be said to put into literary form the jurisprudential issues embodied in two British statutes passed in the wake of the 45 rebellion and together meant to sound the death knell for an independent Scotland and its system of clans. These were the Proscription Act of 1746/1747 and the Heritable Jurisdictions Act of 1746. Both laws were a source of driving concern for Scott. The first was directed in part towards cultural matters; it forbade the wearing of the distinctive form of highland dress, the kilt and tartan. The second statute was directed towards issues of legal dominion; it abolished

29. For a recent study linking literature and law nineteenth-century Britain, see A. Ben-Yishai, Common Precedents: The Presentness of the Past in Victorian Law and Fiction (2013).

30. For a recent discussion of Scottish clan society, see M. Newton, Warriors of the Word: The World of the Scottish Highlanders (2009) 122-163 
the inherited authority of Scottish lairds and clan chiefs to hold court over a variety of disputes arising on their land, the forfeiture of which was the penalty for noncompliance.

The effect of this combined assault on Scottish life was profound, but what emerges strikingly from Waverley is - ironically - Scott's ultimate sympathy with the result. The Mac-Ivors may cut a handsome figure, but in one of the climactic moments of the novel, when chieftain Fergus deals out justice, it is entirely lacking in the due process the rebels themselves will be granted in the courts of England in the conclusion of the book (in the scene, Fergus Mac-Ivor strikes one of his kinsmen on the skull, nearly splitting it open). For Scott, the clan and its legal order had to be overcome in the course of Scottish modernization; indeed, Scott himself long held the county office of Sheriff Depute, a position which evolved to new importance in legal administration precisely in the wake of the Jurisdictions Act.

At the same time, ironically, the new, superior legal order, which took the place of the clan, could be maintained only if the culture that sustained the clan itself -the rich folk life of tartan and ballad Scott so painstakingly chronicled - were given a place of honor in national memory. For reasons similar to those shaping Edward Freeman's constitutional writing, Scott nullified the active political and legal significance of the paramilitary exploits of the Mac-Ivors and their chieftain's difficult law even as he rendered them culturally sustaining, as vital for a unified Britain's common liberal institutions as was Edward's memory of the highlands for his adult personhood. It is this historical consciousness, with all its socio-legal implications, to which Scott gives novelistic expression. A liberal legal order would rest on the embrace in wistful memory of anti-liberal kinship associations; indeed, the fact of that embrace in Scott's own work might be said to have been one of the cultural signs of modern liberalism's true legal advent. The law of a liberal state, that is, would have as its cultural foundation the sympathetic memory of the anti-liberal law of the clan it transcended. The fate of legal centralization and modernization would depend upon whether its supporters could also nurture a positive memory of an ancient source of legal pluralism. Well beyond his literary work, Scott put this ambivalent vision into practice in his celebrated orchestration of King George's visit to Scotland in 1822, which he conceived as a two-week Celtic cultural revival, with the Hanoverian monarch at its head. ${ }^{31}$

Finally, consider medieval private law, specifically how early Anglo-Saxon society conceived of property in land. The nature of landholding in early medieval England carried a special charge because of a fascinating social fact revealed in the Norman land census known as the Domesday Book, which historians of the nineteenth century were coming more fully to understand. The

31. For a detailed treatment of Scott's treatment of Scottish clan life and its relation to modern liberal government during the 1822 celebration, see Weiner, above n. 1, at 191-193. survey revealed that at the time of William's invasion, land was held essentially the same way throughout England, namely in great estates run by a lord of the manor who both held court and had the responsibility for paying taxes to his King; under him, in turn, lived villeins holding unalienable land in exchange for service and, furthermore, holding that land in nearly identical ways across manorial estates. The historical question this raised was how the vast majority of the descendants of the free Germanic conquerors of the fifth century had over time become dependent serfs, and this raised the question of how land was held in England from the start.

Much turned on the answer. Friedrich Engels took a special interest in the subject, drawing from one line of academic work the lesson that early communities had held property in a form of primitive communism. For Engels, ancient peoples were both communal and free, and study of them suggested the possibility that the modern state through economic collectivization could return humanity to a higher level of the 'liberty, equality, and fraternity' of this original social form. ${ }^{32}$ The eminent legal historian Frederic Maitland reached a not unrelated conclusion from a radically different view of the evidence, arguing that Anglo-Saxon property holding had been centered entirely around individuals. Early medieval law, he wrote, knew nothing of groups, whereas a great achievement of modern legal thought was the development of associations with legal personality - a development which should now be advanced and used to facilitate social ends. ${ }^{33}$

The stakes at issue in the matter of Anglo-Saxon property law were not simply hortatory, but often quite immediate. In colonial India, for instance, the subject bore directly on whether traditional restraints on the sale of land or usufruct rights of communal usage should be enforced by British authorities, as they were in the Northwest provinces, or whether a regime of individual, alienable property should instead be established, as it was to some extent in Bombay.

The self-consciously liberal position in this debate was taken by Frederic Seebohm, author of The English Village Community (1883) and Tribal Custom in AngloSaxon Lam (1902). ${ }^{34}$ The titles of these studies suggest their arcane quality, but Seebohm was no antiquarian. He approached his books with a lively sense that their

32. F. Engels, The Origin of the Family, Private Property, and the State in the Light of the Researches of Lewis H. Morgan, ed. and intro. E.B. Leacock (1972) 237 (quoting Morgan, Ancient Society, 552) (Engels's italics).

33. On Maitland, see S.D. White, 'Maitland on Family and Kinship', in J.G. Hudson (ed.), The 'History of English Law': Centenary Essays on 'Pollock and Maitland', Proceedings of the British Academy, Book 89 (1996) 91-114.

34. For a discussion, see J.W. Burrow, " "The Village Community" and the Uses of History in Late Nineteenth-Century England', in N. McKendrick (ed.), Historical Perspectives: Studies in English Thought and Society (1974) 255-284. On the village community, see also H.S. Maine, Village-Communities in the East and West (1871); B.H. Baden-Powell, The Origin and Growth of Village Communities in India (1899); G.L. Gomme, The Village Community (1890) and Primitive Folk-Moots; or, Open-Air Assemblies in Britain (1880). 
subject was vital to the 'practical politics' of 'the great English speaking nations [which] have, so to speak, become charged in our time with the trial of the experiment - let us hope also with the solution of the problem - of freedom and democracy'. ${ }^{35}$ Seebohm's research indicated that Anglo-Saxon property had been held neither communally nor by individuals, but rather by extended family groups. For evidence, Seebohm drew especially on the study of the mergeld, or man-price, the medieval reparation payment due for murder or wrongful death. This early mode of civil compensation was based on a system of kin liability, with tribes having financial responsibility for the actions of their members. From the existence of kin liability and the precise and rather high quantities of pergelds reckoned across tribal groups (too high for any individual to pay), Seebohm deduced the fact of kin-based ownership of land.

Even more dramatically, he showed that the AngloSaxon system of land ownership also had been a regime of despotism. From the point of view of the mergeld, two main types of men existed in early medieval England: those whose pergeld was valued at two monetary units, or hyndes (in the dooms of Alfred), and those whose lives were worth twelve. Two-hynde men originally had been those members of the community who were without kin, and though in Germany or Denmark the descendants of these men could break out of their slave status after a stipulated period of four generations in which their kinship networks grew, in England this status became permanent and generalized to the majority.

The reasons why this happened are not entirely clear, but that the two-hynde class lived in a condition of subordination imposed from above is suggested by the similarity of their manorial holdings as revealed in the Domesday survey. When in the medieval world land had been held by tribal members in a condition of relative freedom, as it had among the Celts, especially in the Welsh kinship network known as the gmely, holdings tended to differentiate themselves over time. But the nature of manorial landholding patterns at the time of William's conquest, combined with the evidence of the pergeld, indicated that Anglo-Saxon England was a society not of primitive communism but rather of primitive tyranny and that common ownership of land and political oppression had historically gone hand in glove. For Seebohm, property in England found its origins in the clan, and it was the dissolution of a society centered around extended kin networks that enabled the establishment of the liberal rule of law, with its individualized property regime and the economic energies it released for the benefit of all - a process, Seebohm argued, that should be borne in mind as the British undertook their global colonial experiment.

\section{Conclusion}

The story of the clan - its early significance, its dissolution, its influence on future legal institutions - might be said to implicate one of the deepest questions of culture and political philosophy raised in the course of the development of modern liberalism. That question is whether liberal government is possible exclusively within societies that treat individuals as deserving of respect because they are valued for their own sake as the very end in itself of law, or whether liberal institutions also can be sustained in societies in which individuals are valued in the final analysis (and here my words gesture to the writings of theologian Jacques Maritain) because they exist within a community of shared, reciprocal submission to a greater good, be it a kinship network, a leveling commitment to economic equality, or a single God. This question was especially raised for British intellectuals by the historic suspicion of Catholicism as a force of political absolutism, a fear not without parallel today, and the vitality of the issue was surely one of the reasons why the question of the clan held such salience in nineteenth-century British legal scholarship and social thought. It helps explain why the etymological relation of King and kin was so interesting; why the figures of Fergus and Flora Mac-Ivor held such symbolic power; and why the otherwise obscure subject of the mergeld could command the attention of so many readers.

It is because the story of the clan resonates with such basic questions about how to live a modern life that I believe the history of how the clan has been remembered is so illuminating - and why that history itself forms part of the ongoing story of the cultural foundations of the rule of law. Just as a culture of honor is foundational to the rule of the clan, so the continually changing memory of the clan is an important cultural foundation for the legal order of the liberal state. A culturalist perspective on legal pluralism allows us to recognize that the liberal rule of law exists in a dialectical relation to the clan as a legal form: that in contemplating the rule of the clan, liberal societies generate the cultural conditions of their own possibility. 